\title{
Active Tense
}

\author{
Sonia Smee
}

Même si je me suis débattue, il me l'a refait. "Je » perdant son espace de sujet, régressant dans la phrase. Ou bien, ce " je » ambulant serait-il moi, jouant l'objet, jouant la morte? Glissement de pronom comme si je devenais cet homme. En même temps, je ne dois pas être lui.

Les scènes du fantasme sont de proverbiales sources d'irritation pour mon psychisme. Leurs intrigues un écho, une répercussion, encore une autre vague frappant la rive d'une survivante. En devenant une protagoniste fantasmatique, j'aspire à apaiser les blessures de l'invasion. Mais je ne suis pas guérie. Le loup n'a pas encore été jeté dehors. Je commence ma recherche en me frayant un passage hors de l'espace passif de l'objet. Je fais un rêve où des fermmes portent des urnes d'acier sur un grand tapis de prière. L'urne, un récipient évasé à sa partie supérieure, circulaire et plein à sa base, est la représentation onirique d'une femme qui retient son urine, luttant contre la gravité. Le rêve présage ce que seront mes exercices de Kegel : tension active, laissant l'espace de l'objet dans une pratique empreinte à la fois de dévotion et de pragmatisme. Je fais mes exercices en pensant à Prométhée, mais je transforme ce titan mythologique en femme, son globe suspendu en elle, débordant sous son ventre et sa vessie, entre ses hanches. Un univers de possibilités.

The night "the change" occurs, completes itself, I am so sleep deprived I hardly care. The baby is four months old. Needs to nurse more often to feed growing body. Wakes more often in the night. Signs of teething. I have started him on solids, hoping this will help him sleep longer. I am a first time parent, a single parent. Just moved to a new city. It's the third move since knowing I was pregnant. Living out of boxes. Patchwork of babysitters. I am deeply fatigued. Blood pressure, heart rate have dropped. I can tell by the lack of circulation to my feet, hands, lips. Eyes are heavy, cool in their sockets from lack of oxygenated blood.

It's fourish in the morning. Can't go back to sleep. Beyond tired. 
Masturbate. Hope that the trigger of violent fantasies won't be necessary in order for me to come. At the same time knowing that fatigue and frustration combust the most easily into this way of thinking/visualizing.

They don't come. Won't. Almost any other night I would have leaned on old thought patterns - something mean and fast to bring on a physical release, then sleep. Tonight, the usual chemistry doesn't work. I am disengaged from that hard chase for climax. I am in a reverie of kindness. I don't know how it is that I am, but I am. The fantasy actors are tender with one another. Listen. Respond. Orgasm arises out of that. Afterwards, inbetween lapses of consciousness, I say to myself: Remember. Know that this is possible. Remember. It ras taken so long to make it so. I think of a mountain top shrouded in fog. I can't see my own feet. I am high in clouds. I smile at the irony, of being too tired to care. I dwell in diffuse light: exhaustion and arrival.

Last week's newspaper included a filler on electronic fantasy games. Apparently there's a new one out, more violent than the rest, with great scenery. It's a hot buy. I try to go the other way with fantasies. Brakes on the violence. The images have been proverbial thorns to my psyche. I want them out. Yet they must serve a function as they have succeeded in staying well lodged; in having a narcotic effect.

Though I fought, he had still done to me: I losing its subject space. I moves on down the sentence.

Or is this moving I me, playing-object, playing-dead?

Thinking about a sentence in this way envelops the pronoun, catches it coming and going, shows how a victim begins to operate in a vacuum.

Yes, he was older, stronger, one pointed in getting what he wanted, devious, injured. Whatever. I was wandering, as children do, in their gardens.

Afterwards, I begin my search. To make passage out of passive, object space. To make events make sense, syntactically and otherwise.

Let me say, without giving these fantasies undue space, that I speak of a child of seven or eight who imagines being kidnapped, stripped; she will be raped. To fight, or show anger, to cry out will only excite her kidnappers. Voice and action are useless. As she grows up, the violating images escalate. She invents, or borrows sequences of torture and humiliation. When the offending man, yes almost always a man, nameless, faceless, comes, then my body could come. 


pronoun
shift as if I
became him. And
at the same
time, I
must not
be him.
Oh, how
many
years does
it take to
say just
this?

Then I would fall heavy asleep. Voice and action buried under a fuzzy endorphin blanket. And conscience? His or mine? In a stupor. Overwhelming guilt - Am I him? Then I am horrible - held at bay by sleep one more time.

Don't feel guilty.

It's just a fantasy.

Enjoy them.

Make art out of them.

Get kinky.

They're just a symptom.

Accept them.

They aren't your fault.

You're angry.

Take care of your anger and they'll go away.

Get on with your life (distract yourself).

Don't ask too many questions, you might not like the answers.

I don't want to go there with you.

Did I feel guilty? Did the fantasies relieve my conscience? Maybe I felt guilty about the real life incestuousness of a brother-in-law's violations, continued betrayal, lies to my sisters, mother, father, everyone really. Indeed, the world of relations all one colossal lie. Or, was I the liar, and a pestilence?

The fantasies were an adrenalin trigger. Just as any extreme is. To fall off the fantasy, to make it real, one has to become as anyone courting danger: 
the mountain climber, motorcyclist, paraglider, the moth to the flame, who, falling off her wings, plunges into the thing she entertains.

I wondered if my abuser was right. I had to submit to, or overpower him: either option proving his point, that while victims and oppressors might reverse their roles, the paradigm stays the same. In becoming a fantasmatic perpetrator did I salve the wounds of invasion? Should I, therefore, leave well enough alone; accept the status quo of how I got off? Never mind that if a man got off using the same images I would shun him, cast him out. Never mind that it seemed as if my abusers went on living inside, parasites devouring their host.

I manage physical triggers. Stay away from television: the passive, isolated space it leads to; its porn clips everywhere, sex and violence sharing the same frame. I wear loose pants, empty my bladder often, don't sit too long, read too long, be alone, be in company, sleep, exercise too long. Food and romance keep me sedated: sweet and bitter.

It helps to have an analysis: the fantasies are not ok, they don't add up. Something is missing in the picture.

It helps to read about addictions. Except that the "drug" is how I think. Makes abstinence tricky.

It helps to meditate.

To see a therapist.

To take the abuser to court.

To go back to school.

To get a job, get on with my life.

It doesn't help to be ashamed.

It doesn't help to go fast to get it over with, nor to go along with an orgy of images.

Sometimes, a few, too few times, it helps to take all afternoon and coax a wellness narrative. Though mostly this feels like propaganda. A few, too few times, I believe the narrative, slip into reverie: Van Gogh's starry night, all lit up, churning, accompanies me; the branches of an apple tree swing wildly in a storm.

But I am not cured, there is no cessation of invading scripts. The wolf has not been sent from the door.

I try talking to the fantasy man. Whispering, "It doesn't have to be this way." But he isn't much interested. Sometimes, curiously, if I lie with my head turned to the right instead of the left, I can repress offending images. All of this occurs over decades. Mostly I submerge myself in relationships. 
A thorny hedge of relationships, a sleeping sickness, grows around my fears. I am waiting for a prince to kiss me awake.

Things fall apart.

I could put together a sketchy narrative: an incident, subsequent incidents, and the development of an internal, seemingly self-generated pornography. Snow White, the shadow of the Wicked Witch, Rapunzel, and nameless, unseeable men were the players. A single act, like the kidnapping, replays itself. No clear memory arises to say who is disguised under the evil knight's armour.

Eventually it happens. A lover turns angry. The anal sex hurts. He won't stop. The fantasy world records him, replays him, but nameless and faceless. I am on the outside watching what happens to the woman. That the fantasy mirrors my life is so obvious now, so clear. The elaborate scripts are memory in disguise. The plot is an echo, a repercussion, one more wave hitting a survivor's shore. "Are you awake? Are you awake?"

kegel / keig( ()1 /, A. H. Kegel, contemporary U.S. physician. Exercises to strengthen the perineal muscles of the female, especially the pubococcygeus and levator ani. This aids in the childbirth process, and in sexual enjoyment. The exercise involves resisting increased abdominal pressure during forced expiration, or resisting the passage of urine in short bursts.

- Taber's Cyclopedic Medical Dictionary

A woman's knowledge of the function of her sexual organs and of her responses is essential (to the treatment of inhibited orgasm). This includes understanding the best methods of stimulating the clitoris and the enhanced vaginal sensations possible by strengthening the voluntary control of the pubococcygeus muscle (PCG). The PCG, which also controls urine flow, contains the nerve endings that provide pleasurable sensation in the outer third of the vagina. Kegel's exercises develop control of the PCG, which is contracted 10 to 15 times tid. In 2 to 3 mo pervaginal muscle tone improves, as does the woman's sense of control.

- The Merck Manual, 16th edition

The Art of Sexual Ecstasy calls these exercises PCPs, an acronym for pubococcygeus pumps. Do your PCPs, it instructs. Pump it up. 
A Kegel in yogic terminology resembles the horse seal, or aswini mudre, and the muhl bandha, a root lock. The Hatha Yoga Pradipika text promises that "the practice of contracting the sphincters in a way resembling the movement of a horse's anus" (oh those old yoga masters used lively metaphors) "will cause a woman's energy to ascend," and "give her great health and magnetism."

"Ovarian kung fu" is described thoroughly by the authors of Healing Love Through Tao, Chia and Chia. They teach wholistic, modern and ancient exercises, specifics of how body and mind can navigate the sexual energy, can heal sexual injury. Lifting the pelvic floor is the primary exercise, for both men and women.

Healing work cannot remake the life as if the injury didn't occur, didn't take up time and space, but it can prevent the injury from getting worse. The little boy, whose fingers got caught in the car door didn't want help. "It won't help," he cried, looking at the snow as I made a compress with it. He wanted the door not to have been slammed. The cold compress will keep the swelling down though. I press it gently on the bruised fingers.

At first I did Kegel exercises for the baby inside, who was waiting, listening. The baby who would feel my body tensions and releases, speed and passivity. Be imprinted with these. I was doing for the baby what I would not do for myself. Before the baby, in that other life, promises of a better sex life had not motivated me to exercise. Threats of a sagging pelvic floor and loss of urinary control in my old age did not induce me. That the baby was coming, that I needed to prepare for the baby's delivery, this created a finite, and irrevocable time line. Alerted me. I wanted to go far into a practice. I put on Mercan Dede's "Sufi Dreams," and assumed the delivery position. Breathing in time to the music.

Oh the longing that this magnificent web of muscles holds. The stories it has to tell. These will change me, listening to them. No wonder I have blocked them. Tears are soft. Spill. I am deep inside a well. Overflows. Longing for history to be other than what it is. For the future to bear fruit. Each contraction pulls water from the well. "Pump" is newly intoned, becomes a tender directive. I don't know it, but I am inside believing. I do as the voice tells. I do my Kegels, 3, 4. I am attentive to the exercise, alert and riding emotional heat at the same time. Lean on Mercan's music: a dreamy, fluted piece with water percussion and an amplified human exhalation, mmpaaaaah, in the foreground, 3, 4, mmpaaaaah.

muscles release memory 
just as raindrops release heat

Muscle memory: I will wet my pants. I am in the physical memory. If I continue the exercises I will wet my pants. I continue. What I feel is memory, not what is occurring. What is occurring is the exercise 3,4 . Then gradually relax the perineum 3, 4. I don't loose control. I am not there, three, in my bed, in the middle of the night with a black panther lying over my feet, waiting to eat me if I move, in my bed which I have wet, waiting until dawn comes to dissolve fear 3,4 . Oh the longing that this magnificent web of muscles holds. For the bed not to be wet, for the dawn to come.

Once opened, the vaginal canal cannot be closed. Labial cells have differentiated into a soft, frilled, relentlessly open vulnerability. The hymen cannot be put back. The vulva cannot refuse entry, no matter how hard, how long, how many times I squeeze. No bony or muscular structure presses it shut the way jaws do a mouth. The cells long to go back, to be as a seamless cover of skin, to not feel this exposure to the light and wind of day. Light, which necessarily filters into the body here, where the baby's head will crown, with all the visions to the new being that that will bring. Wind, which moves the smallest particles, stirs the wheel of lives, which will enter the baby's nostrils and be pushed out again, here. I will become someone else doing these exercises, but I cannot go back to being the girlchild.

I do my Kegels. Mind directs the circular bands, criss-cross of long voluntary muscles layered over short smooth ones, muscles anchored to hips and vertebrae, to contract. Mind directs the webbing of perineal muscle and tendon, connected to womb and bladder, intestines to pull in, lift up the pelvic floor. Mind directs muscles deeper into longing becomes homecoming... Mind is a lover, attends to the body.

I do my Kegels. I have Prometheus in mind. Except I translate this mythological titan into a woman. Her globe is slung, hammocked inside her, bulging under stomach and bladder, from between her hips. A world of what is possible.

What is it called when things fall apart? Entropy, yes?

Gravity wins the trophy.

I do my Kegels, a tussle with gravity,

stoking my body.

A dream: women carry steel urns onto a large prayer rug. Before stepping onto the rug, one at a time, the women squat to urinate into urns, a 
devotional act. Then they wash their hands with their urine. I am repulsed. How can I do as they do? The greater my repulsion the more intense the dream becomes. The women begin to drink their urine. One sucks on a wet, twisted piece of toilet paper. I steel myself, so that I may enter the prayer space. Urn, a metal flask flared at the top, rounded and full at the bottom, is the dream's linguistic and imagistic abbreviation of a woman who contains her flow of urine.

The dream is about Kegels, control of the urinary tract, which means also control of one's self, which means not to be humiliated, not be shamed. Which means active tensing. Leaving object space. Means swallow the world whole. Respond. Means memories. Passing through them. Steely urns are the dream's pun. Devotional attention to the act of elimination, their example. Means differentiating the neural jam of sex-pleasure, which is different from sex-panic, sex-anger, piss, a lust for power, trust and love. Divide each one of these, one from the other. Differentiate what was from what is. Steel myself to go through with this, metaphorically a neurosurgeon's work. The cells protest. They are fused, deeply passive, playing dead. I steel myself to be clear in thoughts, tender with body, patient with practice. The dream foreshadows beautifully what the exercises will be about, devotion and pragmatism at once.

One evening - this is after the baby has been born and I have gone to stay with a friend in the Kootenays - I study anatomy. I want to better visualize what $I$ am doing, why it is so hard to do what the instructions say to do with the Kegels. So many layered, banded, interconnected muscles are depicted in the book. I study from my friend's physiotherapy text. She sits beside me. We are adults playing with the names of muscles, undertanding where they go. "Look at this one," a thick sphincter burrows through the pelvic diaphragm forming the vaginal canal, another forms the anal canal. We review voluntary and automatic nervous systems. Smooth muscles and striped. The first are slow to contract, the second quick. I dream that night that I pass a large tape worm. In the morning, writing the dream down I call the worm depression. Our play has made this worm pass.

When do I imagine the young man? Not for a long time. Decades. At the time of this writing, only a few months ago. I have been in a reverie. He is an innocent. He lies face down on the ground, weeping. He is in a meadow. Surrounded by trees. The air is clear. The sky also. He feels safe. The grasses and trees accept him, regardless of his mind. He isn't judged by 
the trees; nor does he do them harm. He has had the same fantasies as I, with himself cast as abused object. He watches from the outside, passive. He hates what his mind does. I float over him. Yes, I am full of pity. Caritas.

My heart is opened by the reverie. Or does an open heart allow the reverie in? Either way, heart open.

I want to touch his shoulder, give him directions for the way out of his hell.

No words come.

So I hover, guardian presence. I am him. I must be him.

I do my Kegels more and more. I dream a kundalini orgasm. At least the dream self says this is so, that the rising heat and stir in my body is the elusive, famous kundalini rising. I am at peace in mind, in lying beside a lover, peaceful breathing, each of us beside the other

stir then rise of heat until I am all

inside humming 